
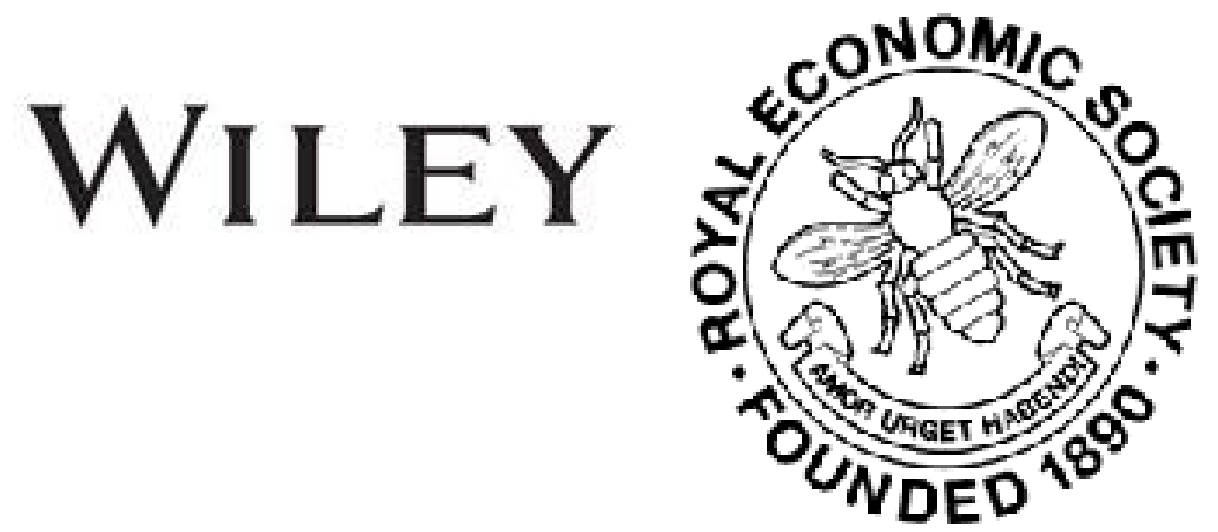

British Trade and German Competition

Author(s): A. W. Flux

Source: The Economic Journal, Vol. 7, No. 25 (Mar., 1897), pp. 34-45

Published by: Wiley on behalf of the Royal Economic Society

Stable URL: http://www.jstor.org/stable/2956957

Accessed: 05-05-2016 03:35 UTC

Your use of the JSTOR archive indicates your acceptance of the Terms \& Conditions of Use, available at

http://about.jstor.org/terms

JSTOR is a not-for-profit service that helps scholars, researchers, and students discover, use, and build upon a wide range of content in a trusted digital archive. We use information technology and tools to increase productivity and facilitate new forms of scholarship. For more information about JSTOR, please contact support@jstor.org.

Wiley, Royal Economic Society are collaborating with JSTOR to digitize, preserve and extend access to The Economic Journal 


\section{BRITISH TRADE AND GERMAN COMPETITION}

So long as the shadow of trade depression hung over this country, the controversy as to the relative progress of German and British trade excited no small interest in all classes of the community. Now that we are able to welcome more assured signs of trade revival, it may be expected that, for a time, the outcry in relation to foreign competition will be less audible. Cabinet Ministers have repeatedly assured us that matters are far less serious than pessimist orators and. writers represent, and we are promised ample confirmation of their statements in a forthcoming report dealing with the question in a detailed and practical manner. It may not be without advantage, without waiting for this report, ${ }^{1}$ to attempt to show that the material already available, when fairly examined, is far from lending support to the view that England has been already beaten in the contest for the supremacy in the world's trade. The method adopted will, in part, be that employed in articles published in the ECONOMIC JournaL in 1894, the results of continuing to the latest available date the comparisons there made being indicated. But, further than this, a closer and more careful examination of the records has thrown some side-lights on the material, which possess no little interest in view of certain popular delusions.

In using the various statistical records which are naturally relied upon for evidence, we need to adopt some systematic method of comparison. A suitable selection of dates, especially if they be differently chosen for the two or more countries whose trade is compared, may permit of a presentation of accurate figures which nevertheless suggest entirely false conclusions. Two points will be kept in mind in respect to this selection of dates for comparison. The one, that exceptional but temporary fluctuations must not be allowed to prejudice the case: this will be, in part at least, avoided by comparing, not single years, but groups of three years. [Larger groups of years would be more

1 Since these pages were printed, the Report has been published.-Edirors. 
suitable for some purposes, but their use would involve too great appearance of artificiality.] The second point is that progress cannot be justly estimated by comparing merely the conditions of the middle of a trade-depression with those of years when trade-revival has reached its utmost development. The year 1883 should be compared with 1890, the year 1886 with 1894, if we would measure progress fairly; better still, make both comparisons, and modify them in the manner stated a few lines back.

The very generally credited statement that Germany and some neighbouring nations are increasing their exports of domestic produce far more rapidly than our own country needs modification when the whole of the figures are viewed together, not, as is commonly done, a comparison made of the movement from some one date to another.

Viewing the German export trade first, it is a striking, but much neglected, fact, that since 1883 there has been as much downward as upward movement in the changes from year to year. After an almost unbroken rise from the date of the earliest figures, 1872, till 1883, the movement was reversed in 1884 and 1885, the lowest figure reached being fully $12 \frac{1}{2}$ per cent. below the record of 1883 . The exports of British and Irish produce from the United Kingdom reached a maximum a year earlier, a minimum a year later than was the case with the German exports, but the minimum was hardly 12 per cent. below the maximum. The upward movement was then resumed, the highest figures being reached in 1890 in both cases. The upward movement of the German figures fell short of $15 \frac{1}{2}$ per cent., that of the English figures exceeded 23 per cent. The next part of the movement is less easy to compare, since the German figures changed somewhat irregularly, reaching a minimum in 1892, but falling back in 1894 almost to the figure from which the 1893 rise began. In this case the decline of the British figures was rather over 18 per cent., the German decline being about 11 per cent., more or less according as 1892 or 1894 be taken as the minimum by which to calculate.

If we remember that for a quarter of a century before 1872 our own export trade increased with hardly a check at a rate greater than that of the German trade-growth between 1873 and 1883, we shall be inclined to give its due weight to the fact that, as British trade has moved upward with hesitating steps during the last twenty-five years, but did exceed in 1890 the record of 1872 in spite of the fall of prices (the inflated values and trade 
movements of 1872 to 1874 are hardly a just platform from which to register future progress, considering the part played in that inflation by the consequences of the Franco-German war); so also, since 1883, the upward steps of German export-trade have been hesitating, and the advance has been discontinuous in about the same degree as that in the export trade of our own country. We have remarked a slight lack of synchronism in the two movements, and it will therefore be readily seen that the utility of the comparison of the upward movements now in progress in both cases, but probably not yet complete in either, would not be likely to be of very great value. The following comparison may be useful as a numerical comment on what precedes.

\begin{tabular}{|c|c|c|c|c|}
\hline Special Exports of & $\begin{array}{l}\text { Annual Aver- } \\
\text { age, 1882-84. }\end{array}$ & $\begin{array}{l}\text { Annual Aver- } \\
\text { aje, 1885-87. }\end{array}$ & $\begin{array}{l}\text { Annual Aver- } \\
\text { age, 18s9-91. }\end{array}$ & $\begin{array}{l}\text { Annual Aver- } \\
\text { age, 1892-94. }\end{array}$ \\
\hline $\begin{array}{l}\text { United Kingdom } \ldots \ldots \ldots \ldots \ldots \ldots \\
\text { Germany } \ldots \ldots \ldots \ldots \ldots \ldots \ldots \ldots \\
\text { France } \ldots \ldots \ldots \ldots \ldots \ldots \ldots \ldots \ldots \ldots \\
\text { Holland } \ldots \ldots \ldots \ldots \ldots \ldots \ldots \ldots \ldots \\
\text { Belgium } \ldots \ldots \ldots \ldots \ldots \ldots \ldots \ldots \\
\text { United States } \ldots \ldots \ldots \ldots \ldots \ldots \ldots\end{array}$ & $\begin{array}{l}\text { Million } £ \\
238 \cdot 1 \\
161 \cdot 1 \\
136 \cdot 8 \\
63 \cdot 0 \\
53 \cdot 4 \\
157 \cdot 1\end{array}$ & $\begin{array}{l}\text { Million £ } \\
215 \cdot 9 \\
149 \cdot 7 \\
127 \cdot 8 \\
78 \cdot 6 \\
48 \cdot 3 \\
145 \cdot 5\end{array}$ & $\begin{array}{l}\text { Million } £ \\
253 \cdot 2 \\
161 \cdot 2 \\
147 \cdot 0 \\
91 \cdot 6 \\
58 \cdot 9 \\
170 \cdot 0\end{array}$ & $\begin{array}{l}\text { Million } £ \\
220 \cdot 3 \\
150 \cdot 1 \\
130 \cdot 3 \\
93 \cdot 2 \\
53 \cdot 7 \\
188 \cdot 6\end{array}$ \\
\hline
\end{tabular}

The year of maximum prosperity, 1883, is made the centre of the first period in this comparison, the year 1890 similarly the centre of the third period. The other two periods are simply the three years immediately following those already named. It will be observed that Germany shows the least sign of progress of any of the group. Holland registers practically uninterrupted progress throughout the period: the highest point was reached in 1891, with $94 \cdot 8$ millions of exports, from which figure 1894 showed a fall of two millions. The United States, too, had made great advances.

A further commentary on the extent to which our manufacturing rivals are succeeding in their business may be found in the returns of the exports of manufactures from Germany, Holland, France and the United States. The term is not likely to have precisely the same interpretation in all these countries, but the returns are none the less instructive, and the corresponding figures for Belgium would, if available, render them still more useful.

Exports of Domestic Manufactures from Germany, France, Holland, and U.S.A. (in million £). $\begin{array}{cccc}\text { Average 1882-84. } & \text { Average 1885-87. } & \text { Average 1889-91. } & \text { Average 1892-94. } \\ 217 \cdot 2 & 213 \cdot 2 & 235 \cdot 6 & 223 \cdot 7\end{array}$ $213 \cdot 2$ $235 \cdot 6$

$223 \cdot 7$ 
The continuous advance of the domestic exports of Holland does not show in so marked a form in this department. It should be added that the average of 1884-86 was 211 millions, and thus below that of 1884-87. The average of 1893-95 is about five millions above the average of 1892-94. The rate of advance, though somewhat greater than that shown by our own exports, hardly looks like beating us out of the field very rapidly.

To further examine the competition thus indicated in bulk, we may try to trace to their destination the exports of our neighbours and ourselves. Our comparison with Germany in particular is rendered difficult by the fact that the German figures of destination underwent a very great change after 1889 , when the great bulk of exports to and imports from the Hanse Towns were divided among the true countries of destination and origin. As a result of this the comparison of the share of our imports which Germany supplies with the share supplied by us of German imports cannot be made directly, and we are compelled to take the English returns for both movements. Our exports are thus somewhat undervalued, being estimated at the port of shipinent from England, not, as is desirable for a just comparison, at the port of arrival in Germany. The proportions of increase or decrease are sufficiently indicated, however, assuming that the accuracy of the determination of the country of destination (or of origin in the case of imports) has undergone no change during the period of comparison. It will be suggested later, that this assumption does not represent the facts with complete accuracy.

\begin{tabular}{|c|c|c|c|c|}
\hline & $\begin{array}{l}\text { Average } \\
\text { 1882-84. }\end{array}$ & $\begin{array}{l}\text { Arerage } \\
1885-87 .\end{array}$ & $\begin{array}{l}\text { Average } \\
1889-91 .\end{array}$ & $\begin{array}{l}\text { Average } \\
1892-94 .\end{array}$ \\
\hline $\begin{array}{l}\text { British Exports to Germany } . . . \ldots . \\
\text { British Imports from Germany } \ldots . . .\end{array}$ & $\begin{array}{c}\text { Million } £ \\
31 \cdot 0 \\
25 \cdot 7\end{array}$ & $\begin{array}{c}\text { Million } £ \\
26 \cdot 9 \\
23 \cdot 0\end{array}$ & $\begin{array}{c}\text { Million } \& \\
30 \cdot 6 \\
26 \cdot 7\end{array}$ & $\begin{array}{c}\text { Million } £ \\
28 \cdot 9 \\
26 \cdot 3\end{array}$ \\
\hline British Imports from Germany & & & & 20.3 \\
\hline
\end{tabular}

The later figures now available (taking those for 1896 as given by Mr. Ritchie at Wolverhampton on January 27th) show that the average exports for the three years 1894-96 have risen to $31 \cdot 8$ millions, while the imports have increased to $27 \cdot 1$ millions on the average of the same three years. These figures, though indicating no startling invasion of home markets by German goods, do not show the movement in quite as favourable a light as the figures for single years quoted by Mr. Chamberlain at Birmingham in November last. The accident that the latest returns then available were those of 1895 caused the ten-years comparison which 
was made to start from the lowest figures recorded for a long time. The imports from Germany were the lowest since 1876, though, 'tis true, higher than those for any year before that date. The exports were the lowest since 1866 . The imports for 1895, with which the comparison was made, have only been beaten in 1883, 1889 and 1891, till 1896 is reached, the returns for which reach a figure but little below the previous record of 1883 . The exports for 1895 were the highest since 1875 when the inflation following the war had not yet died away. Had the comparison been made of 1885 with 1894, as was done with the totals of the two countries' trade, the relative advance shown would have been quite other than that to which attention was called. Failing a consideration of the figures for each of the last fifteen years, the summary given above represents tolerably fairly the actual movement. It may be added that the three years 1884-86 showed an average of 22.7 millions for the imports from Germany, being the smallest figure of imports for any three consecutive years in the last twenty years. It is further worthy of note that, among the exports, our own domestic produce occupies fully as important a place as formerly.

Let us now turn to the somewhat wider field of the group of countries already dealt with, commonly regarded as our most. important rivals. To these countries we still export nearly onethird of our total exports of British and Irish produce and manufactures, and, of our total exports of all kinds, over 40 per cent. The case stands thus, using, for brevity, the term " rivals" to. indicate, in this instance, Germany, Holland, Belgium, France and the United States.

\begin{tabular}{|c|c|c|c|c|}
\hline & $\begin{array}{l}\text { Average } \\
1882-84 .\end{array}$ & $\begin{array}{l}\text { A verage } \\
1885-87\end{array}$ & $\begin{array}{l}\text { Average } \\
1889-91 .\end{array}$ & $\begin{array}{l}\text { Average } \\
1: 92-94 \text {. }\end{array}$ \\
\hline Exports from U.K. to Rivals .......... & $\begin{array}{l}\text { Million } \mathfrak{E} \\
127 \cdot 3\end{array}$ & $\begin{array}{l}\text { Million } £ \\
112 \cdot 9\end{array}$ & $\underset{127 \cdot 5}{\operatorname{Million}} \mathfrak{L}$ & $\begin{array}{l}\text { Million } \varepsilon \\
113 \cdot 2\end{array}$ \\
\hline $\begin{array}{l}\text { Imports of Rivals from U.K. for } \\
\text { home consumption }\end{array}$ & $119 \cdot 6$ & $103 \cdot 6$ & $124 \cdot 6$ & $107 \cdot 2$ \\
\hline
\end{tabular}

It will be observed that the figures of this trade derived from the customs returns on the two sides approximate more closely in the later years than in the earlier. Unless the charges for freight, insurance and commissions are heavier in proportion to the value of the goods than formerly, the suggestion of these figures is that our exports are assigned more accurately than formerly to their true ultimate destination. Even if the difference be small, it is in the right direction. The consideration of the 
figures of transit trade supplied by Belgium gives even more plausibility to this suggestion. With the remark that we appear to hold our ground in the markets of our rivals themselves, we may proceed to compare our own with German trade in this respect.

The change in the German returns in the matter of the Hanse Towns, already referred to, prevents a useful comparison on the same basis as the above. In the case of German exports to the United Kingdom and to the United States, so great a change took place in the recorded figures that it would be quite fallacious to attempt a comparison with years before 1889. The returns of exports to Holland, Belgium and France, however, appear, as might be expected, to be but slightly affected by the inclusion of the Hanse Towns in the Zollverein. A comparison with the figures of these countries themselves confirms the impression produced by the German figures. We may, therefore, use the recorded figures for this part of the German trade with but little reserve. We find the comparison works out as follows:-

\begin{tabular}{|c|c|c|c|c|}
\hline & $\begin{array}{l}\text { Average } \\
1882-84 .\end{array}$ & $\begin{array}{l}\text { Average } \\
1885-87 .\end{array}$ & $\begin{array}{l}\text { Average } \\
1889-91 .\end{array}$ & $\begin{array}{l}\text { Average } \\
1892-94 .\end{array}$ \\
\hline & Million $£$ & Million $£$ & Million $£$ & Million $£$ \\
\hline $\begin{array}{l}\text { Holland, Belgium, and } \\
\text { France } . . . \ldots \ldots \ldots \ldots \ldots \ldots \ldots . . . . . . . .\end{array}$ & $36 \cdot 5$ & $31 \cdot 1$ & $31 \cdot 5$ & $29 \cdot 1$ \\
\hline $\begin{array}{c}\text { Special Imports from Ger- } \\
\text { many of Holland, } \\
\text { gium, and France } \\
. . . .\end{array}$ & $52 \cdot 9$ & $45 \cdot 7$ & $43 \cdot 8$ & $43 \cdot 5$ \\
\hline $\begin{array}{c}\text { British Exports to Holland, } \\
\text { Belgium, and France }\end{array}$ & $60 \cdot 2(35 \cdot 6)$ & $49 \cdot 7(31 \cdot 1)$ & $53 \cdot 2(33 \cdot 1)$ & $48 \cdot 3(29 \cdot 4)$ \\
\hline and France & $58 \cdot 5$ & $49 \cdot 1$ & $55 \cdot 2$ & $49 \cdot 1$ \\
\hline
\end{tabular}

[The figures in brackets are the Exports of British and Irish Produce.]

So far as it applies to England, this comparison confirms the suggestion of more accurate descriptions of destinations of exports in recent years. In the case of Germany, as in our own case, a. considerable proportion of the export to her neighbours is of the nature of transit trade, but in recent years we have not even the value of the total of this trade supplied. The above comparison appears to indicate that the export from Germany to her neighbours on the west is decreasing, our own export to the same countries also decreasing, but less rapidly and less steadily, that is, the decrease is interrupted by considerable revivals from time to 
time. A study of the figures, so far as they relate to Germany, for earlier years, does not modify this impression. The German returns give no help beyond 1880, but, as we have seen that the general tendency of the trade as indicated by the import figures of the other countries, is the same as that shown by the German returns, their indications may be used for earlier years. Roughly speaking, these figures indicated a steady growth in this trade till the year 1882, after which comes a decrease only slightly interrupted by the last trade revival. Viewed in the same way, the German export to the rest of the world would appear to have increased till 1890. The decrease since that date may be merely the result of general trade depression, not an indication of any permanent tendency.

A view of the distribution of our export trade will assist in a correct estimation of the actual present situation. The following shows the

Exports from United Kingdom of British and Irish Produce.

\begin{tabular}{|c|c|c|c|c|c|}
\hline To & $\begin{array}{l}\text { A verage } \\
18>2-84 .\end{array}$ & $\begin{array}{l}\text { Average } \\
1885-87 .\end{array}$ & $\begin{array}{l}\text { A rerage } \\
\text { 1ss9-91. }\end{array}$ & $\begin{array}{l}\text { A verage } \\
1892-94\end{array}$ & 1895. \\
\hline & Million \& & Million $\mathfrak{E}$ & Million $\mathfrak{E}$ & Million $£$ & Million $£$ \\
\hline $\begin{array}{l}\text { Germany, Holland, } \text { Belgium, } \\
\text { France, and U.S.A. }\end{array}$ & $81 \cdot 5$ & $71 \cdot 9$ & $81 \cdot 9$ & $70 \cdot 9$ & $77 \cdot 1$ \\
\hline British Possessions $\quad \ldots \ldots \ldots \ldots \ldots \ldots$ & $83 \cdot 1$ & $76 \cdot 3$ & $85 \cdot 5$ & $73 \cdot 1$ & $70 \cdot 0$ \\
\hline Rest of the World...$\ldots \ldots \ldots \ldots \ldots \ldots$ & $73 \cdot 5$ & $67 \cdot 7$ & $85 \cdot 8$ & $76 \cdot 3$ & $78 \cdot 8$ \\
\hline
\end{tabular}

A first glance at this table suggests extremely unpleasant reflections. The trade with our rivals is fairly maintained, that with the rest of the world outside the British Empire shows extremely satisfactory expansion, but our exports to our Colonies appear to be dwindling. For this there are two reasons. Nearly 40 per cent. of our exports to British Possessions are sent to India. The expansion of this trade has been hampered by the continual fall in the exchange. With a fall of more than 12 per cent. in the average rate obtained for council bills between 1891-2 and 1893-4, we might expect that this section of our export trade would manifest even greater depression than the trade with other countries not so affected. A more obvious cause than this, and one more marked in its effects, is the financial collapse in our Australian Colonies in 1892. How much of the recent inelasticity in our colonial markets is due to this cause mav be seen from the following comparison: 
Exports of British and Irish Produce.

\begin{tabular}{|c|c|c|c|c|c|}
\hline To & $\begin{array}{l}\text { Average } \\
1882-84 .\end{array}$ & $\begin{array}{l}\text { A verage } \\
1885-87 .\end{array}$ & $\begin{array}{l}\text { Average } \\
1889-91 .\end{array}$ & $\begin{array}{l}\text { Average } \\
1892-94 .\end{array}$ & 1895. \\
\hline 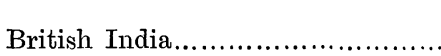 & $\begin{array}{c}\text { Million } \\
30.5\end{array}$ & $\begin{array}{c}\text { Million } £ \\
30 \cdot 4\end{array}$ & $\begin{array}{c}\text { Million } £ \\
31.9\end{array}$ & $\begin{array}{c}\text { Million } £ \\
28 \cdot 7\end{array}$ & $\begin{array}{c}\text { Million } \\
24 \cdot 7\end{array}$ \\
\hline Australia (including Tasmania) ... & $20 \cdot 4$ & 190 & $20 \cdot 1$ & $13 \cdot 5$ & $14 \cdot 2$ \\
\hline Other British Possessions ........... & $32 \cdot 2$ & $26 \cdot 9$ & $33 \cdot 5$ & $30 \cdot 9$ & $31 \cdot 1$ \\
\hline
\end{tabular}

Apart from the two causes noted, the expansion of our exports to other parts of the Empire is not unsatisfactory. These causes affect some 60 per cent. of the trade; hence the whole, when viewed in the mass, appears worse than the reality. Doubtless the Australian markets will, in due time, again absorb about as great a share of our products, or nearly so, as before 1892 . Bearing in mind the extent of these influences, and noting the progress of our exports to the world outside the Empire, and the countries of our rivals themselves, the impression of approaching doom is pleasantly relieved.

The comparison of the relative progress of Britain and Germany, which cannot be made from the German figures themselves, owing to the change in the mode of compilation, can be partly effected by the method employed in the articles in this Journal already referred to. A summary of results will be sufficient here. It should be noted, in considering these results, that the progress of German trade is exaggerated in them for two reasons at least. One is that some countries now separate their imports from Germany from the general mass of those from " other countries," where they were formerly buried (and that the knowledge of the real origin is more accurate); another, that some German produce formerly purchased in this country, and entered as from Great Britain, is now obtained direct. Thus part of the recorded increase is apparent only, and does not represent a real increase of the proportion of German-made articles in the respective countries whose returns contribute to the following summary:

Imports of Russia, Norway, Sweden, Denmark, Holland, Belgium, France, Italy, Spain, Portugal, and Roumania.

\begin{tabular}{|c|c|c|c|c|c|}
\hline \multirow{2}{*}{$\begin{array}{l}\text { Average of } \\
\text { Years }\end{array}$} & \multirow{2}{*}{$\begin{array}{c}\text { Total } \\
\text { (Million } £ \text { ) }\end{array}$} & \multicolumn{2}{|c|}{ From United Kingdom. } & \multicolumn{2}{|c|}{ From Germany. } \\
\hline & & Million $£$. & Per cent. & Nillion $£$. & Per cent. \\
\hline $1877-79$ & $465 \cdot 6$ & $94 \cdot 8$ & $20 \cdot 4$ & $81 \cdot 2$ & $17 \cdot 4$ \\
\hline $1882-84$ & 533.5 & $\begin{array}{r}.105 \cdot 1 \\
100\end{array}$ & $19 \cdot 7$ & $94 \cdot 2$ & $17 \cdot 7$ \\
\hline $1885-87$ & $502 \cdot 3$ & $90 \cdot 3$ & $18 \cdot 0$ & $83 \cdot 9$ & $16 \cdot 7$ \\
\hline $1889-91$ & $556 \cdot 9$ & $104 \cdot 1$ & $18 \cdot 7$ & $84 \cdot 1$ & $15 \cdot 1$ \\
\hline $1892-94$ & $530 \cdot 2$ & $94 \cdot 4$ & $17 \cdot 7$ & $82 \cdot 9$ & $15 \cdot 6$ \\
\hline
\end{tabular}


Imports of U.S.A., Argentina, Chili, Uruguay, Egypt, and Japan.

(NoTE.-The Japanese returns only go back to 1880 . Germany is not separately given in the Egyptian returns till 1884.)

\begin{tabular}{|c|c|c|c|c|c|}
\hline $\begin{array}{c}\text { Average of } \\
\text { Year's }\end{array}$ & $\begin{array}{c}\text { Total } \\
\text { (Million £). }\end{array}$ & \multicolumn{2}{|c|}{ From United Kinglom. } & \multicolumn{2}{|c|}{ From Germany. } \\
\cline { 1 - 5 } & & Million £. & Per cent. & Million £. & Per cent. \\
\hline & & & & $8 \cdot 4$ & $7 \cdot 3$ \\
$1877-79$ & $115 \cdot 0$ & $30 \cdot 1$ & $26 \cdot 2$ & $16 \cdot 4$ & $8 \cdot 6$ \\
$1882-84$ & $191 \cdot 6$ & $54 \cdot 8$ & $28 \cdot 6$ & $19 \cdot 6$ & $10 \cdot 8$ \\
$1885-87$ & $181 \cdot 9$ & $50 \cdot 0$ & $27 \cdot 5$ & $26 \cdot 8$ & $11 \cdot 6$ \\
$1889-91$ & $230 \cdot 8$ & $62 \cdot 1$ & $26 \cdot 9$ & $24 \cdot 7$ & $11 \cdot 0$ \\
$1892-94$ & $222 \cdot 5$ & $52 \cdot 8$ & $23 \cdot 4$ & & \\
\hline
\end{tabular}

Imports of British Possessions.

(NotE. - The rupee is converted at the average rate of council bills.)

\begin{tabular}{|c|c|c|c|c|c|}
\hline \multirow{2}{*}{$\begin{array}{c}\text { Average of } \\
\text { Years }\end{array}$} & $\begin{array}{c}\text { Total } \\
\text { (Minlion £). }\end{array}$ & \multicolumn{2}{|c|}{ From United Kingdom. } & \multicolumn{2}{c|}{ From Germany. } \\
\cline { 3 - 6 } & & Million \&. & Per cent. & Million £. & Per cent. \\
\hline & $133 \cdot 3$ & $81 \cdot 3$ & $61 \cdot 0$. & $0 \cdot 4$ & $0 \cdot 3$ \\
$1877-79$ & $166 \cdot 9$ & $101 \cdot 0$ & $60 \cdot 5$ & $1 \cdot 3$ & $0 \cdot 8$ \\
$1882-84$ & $156 \cdot 9$ & $94 \cdot 3$ & $60 \cdot 1$ & $1 \cdot 8$ & $1 \cdot 2$ \\
$1885-87$ & $183 \cdot 8$ & $108 \cdot 1$ & $58 \cdot 8$ & $3 \cdot 7$ & $2 \cdot 0$ \\
$1889-91$ & $165 \cdot 6$ & $92 \cdot 9$ & $56 \cdot 1$ & $4 \cdot 1$ & $2 \cdot 5$ \\
$1892-94$ & & & & & \\
\hline
\end{tabular}

These three tables, when taken together, give us the following summary of the imports of so much of the world as is included in them. If the totals of the imports and exports of the world, given by Dr. von Juraschek, in the Übersichten derWeltwirthschaft, be assumed to be correct, about one-seventh only of the world's import and export trade does not come under examination.

\begin{tabular}{|c|c|c|c|c|c|}
\hline $\begin{array}{c}\text { A verage of } \\
\text { Year's }\end{array}$ & $\begin{array}{c}\text { Total of } \\
\text { Imports } \\
\text { (Million \&). }\end{array}$ & \multicolumn{2}{|c|}{ From United Kingdom. } & \multicolumn{2}{|c|}{ From Germany. } \\
\hline & Million £. & Per cent. & Million £. & Per cent. \\
\hline $1877-79$ & $713 \cdot 9$ & $206 \cdot 2$ & $28 \cdot 9$ & $90 \cdot 0$ & $12 \cdot 6$ \\
$1882-84$ & $892 \cdot 0$ & $260 \cdot 9$ & $29 \cdot 2$ & $111 \cdot 9$ & $12 \cdot 5$ \\
$1885-87$ & $841 \cdot 1$ & $234 \cdot 6$ & $27 \cdot 9$ & $105 \cdot 3$ & $12 \cdot 5$ \\
$1889-91$ & $971 \cdot 5$ & $274 \cdot 3$ & $28 \cdot 2$ & $114 \cdot 6$ & $11 \cdot 8$ \\
$1892-94$ & $918 \cdot 3$ & $240 \cdot 1$ & $26 \cdot 1$ & $111 \cdot 7$ & $12 \cdot 2$ \\
\hline
\end{tabular}

Some slight differences between the above figures, and some of those given in this Journal in 1894, are due to a revision of the returns then available, especially in reference to the trade between Germany and certain of our colonies.

The general conclusion derived from the figures of export trade here reviewed is that, but for exceptional circumstances 
in Australia, the recent depression would have compared not unfavourably with former depressions; still more so had not the large trade with India been disturbed by the continual fall of exchange, and that of the United States by tariff changes and a quite unusual dislocation of business which characterised 1894.

A few words on another subject will add strength to the confidence derived from what precedes. If we turn to the returns of shipping owned and shipping business done, we find that progress in these directions still continues.

The records of tonnage owned in different countries, which are compiled by very different authorities, confirm one another in the general conclusion, even though the detail be different. Dr. von Juraschek, in the publication already quoted, credits Great Britain and Ireland with the ownership of 42.7 per cent. of the tonnage of the world, or, taking steam tonnage as equivalent in carrying power to three times as much sailing tonnage, with just over 50 per cent. of the carrying power of the world. Germany owned, according to this authority, only about 7 per cent. when tested by either criterion. 'The date of these figures is the beginning of 1893 .

A comparison of 1895 with ten years before, which was made by Mr. Worthington C. Ford, in one of those admirable supplements to the usual returns which have made his monthly summaries of the trade returns of the United States so interesting and instructive, shows that the increase of tonnage owned in the United Kingdom and in Germany during those ten years was about 21 per cent. in each case, and indicates that the proportion of British tonnage to that of the world is increasing. The figures of Lloyd's register (which may be found in Whitaker's Almanack), give a like result. The tonnage owned in the United Kingdom increased from $43 \frac{3}{4}$ to 48 per cent. of that of the world in the ten years preceding the last record, which refers to 1896-7, and, if we reckon effectiveness as stated above, namely, 1 steam ton $=3$ sailing tons, the effectiveness of the British-owned mercantile marine increased from 51.6 to 52.7 per cent. of that of the world. The German mercantile marine increased from 6.5 to $7 \cdot 6$ per cent. of the world's tonnage, and, in effectiveness, from 6.2 to 7.9 per cent. This is a more rapid progress than that of Great Britain, but our rate of progress when our mercantile marine was of a magnitude comparable in tonnage or in effectiveness with Germany's present shipping, would show that our present slower progress relatively is attributable to the enormous bulk of the shipping already acquired. In the ten years referred to, the 
increase of British shipping was about 50 per cent. more in tonnage, considerably more than the double in effectiveness (on the assumed basis) of the whole of the merchant shipping owned in Germany at the present time.

It may be remarked, in passing, that in regard to ownership of shipping and shipping movements, the changes from year to year are not so rapid as to render it necessary to resort to comparisons of periods. Single-year comparisons give a view of the actual facts, which is, in general, extremely close to that afforded by periods of years. Comparing 1894 with 1885, the increase of entrances and clearances of ships with cargoes at British ports was nearly 22 per cent., at German ports $41 \frac{1}{2}$ per cent. The actual British increase was about seven-eighths of Germany's total in 1885. The comparison with 1884 would have shown more favourably for the United Kingdom, owing to an irregularity in the progress of the figures. Situated as our country is, all its external trade depends on shipping, while much of the external trade of Germany takes place across its land frontiers. Still, it may not be out of place to recall the fact that in 1850 the shipping movements in British ports in the foreign trade were about the same in amount as those of Germany in 1885, and that the growth during the following decade was fully 70 per cent. Looking back, we find that the rate of growth both of shipping owned and of entrances and clearances is slackening. Were both countries to maintain their present rate of growth, Germany would overtake us in something like a century, but the slowing-down process will defer that event, especially as the consideration of the past and the recent changes of both sets of figures appear to indicate a more rapid slowing of the German rate of increase than of our own. There is a further point to be noted, and that is, that even in the coasting trade, the proportion of foreign vessels is not inconsiderable (recently about 10 per cent.) in the case of the German trade, while it is less than the half of one per cent. in the British coasting trade. In the foreign trade about 46 per cent. of the shipping entered and cleared at German ports is German, and of the remainder nearly two-thirds is British. In British ports about 74 per cent. of the shipping is British, and of the remainder not quite one-sixth is German. The total of entrances and clearances with cargoes is three-and-a-half times as great at British as at German ports (foreign trade only), and the British shipping in German ports is not far short of twoand-a-half times as much as the German shipping in British ports. Thus, apart from any other cause, the increase in German 
foreign trade tends to the prosperity of one important English industry.

The increase in the coasting trade is, it may be remarked, satisfactory, and may, perhaps, be taken as one small indication of expansion of home trade, without which growth of oversea trade would afford less reason for congratulation.

In conclusion, there seems no reason for thinking that it is yet too late in the day to prevent the loss of any notable portion of our foreign trade. If we can remedy such defects as those noted by Mr. Bruford in his report on the trade of Victoria, where trade was lost because tacks were sent in paper packages instead of in cardboard boxes, and cartridges were sent in packages of a hundred, while customers preferred packages of twenty-five ; if more attention to the tastes of their customers be given by those who have, by their actions, called forth such rebukes as that of Mr. Chamberlain, quoted in the last number of the JournaL, if the example of our best manufacturers and merchants be copied by the rest, if the delusion be dispelled that people will be contented with what is offered provided that they can be persuaded that they cannot get anything more to their taste, if the severity of foreign competition arouse us in time to the real need for exertion on the part of every one concerned, there is still left a trade which, in the present condition, is the envy of the world, and which draws from foreigners many a complaint of the severity of the competition of England with themselves.

It may be perfectly true when an Englishman says (to quote the report of Her Majesty's Consul at Teneriffe) "This is the best article of its kind; take it or leave it, but it is the cheapest in the long run." Yet the "take it or leave it" policy is a mistake, even if prejudice do not over-estimate the goods offered. When he can be suited elsewhere, we may be sure the foreigner will not take English goods unless they suit him.

A. W. FLuX

Note.-For comparison with the figures at the foot of p. 36, the following, derived from information in Sir Courtenay Boyle's recent memorandum may be useful.

Exports of manufactured and partly manufactured Articles of British and Irish Produce (in million £).

Average 1885-87. Average 1889-91. $\begin{array}{ccccc}212 \cdot 8 & 192.6 & 221 \cdot 4 & 190 \cdot 4 & 209 \cdot 9\end{array}$

The anticipation expressed on p. 41, finds some justification in the following figures for 1896. Exports of British and Irish Produce: to British India, 30 millions, to Australia, $17 \cdot 9$ millions, to other British possessions, 36 millions. 